Historic, Archive Document

Do not assume content reflects current scientific knowledge, policies, or practices. 



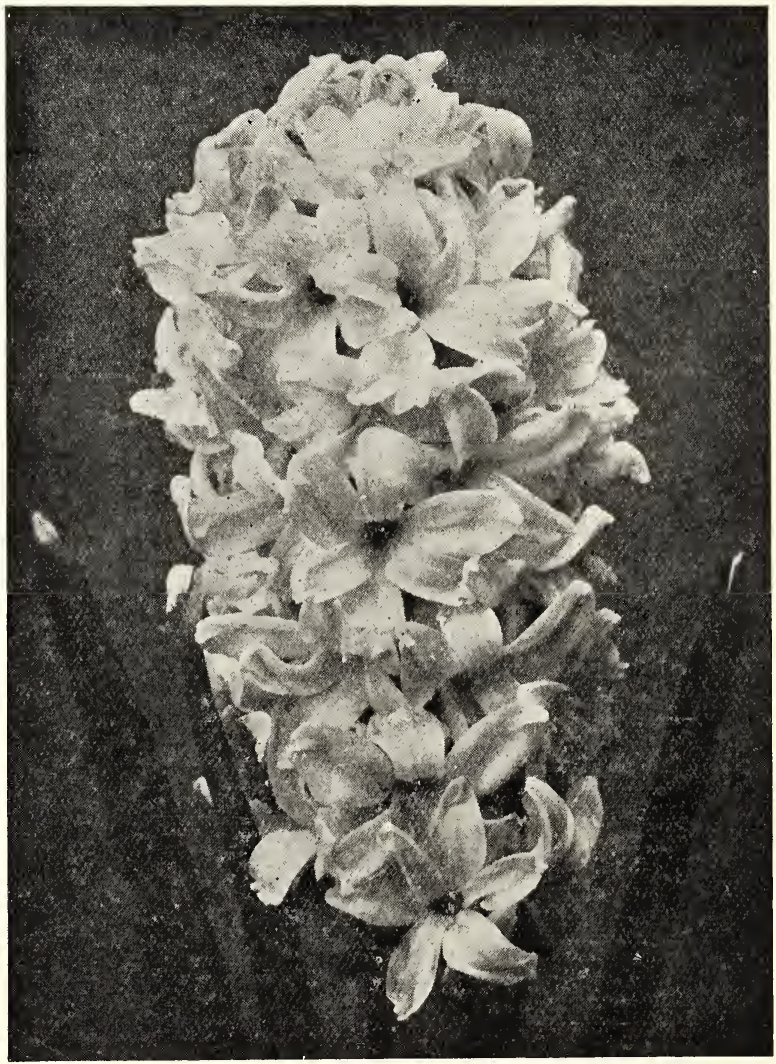

HYACINTH, "LA GRANDESSE." 


\section{A DESCRIPTIVE CATALOGUE OF}

\section{BULBS}

AND

\section{BULBOUS PLANTS}

Issued jointly by

THE ASSOCIATED FIRMS:

C. Starke \& Co. Ltd.

Agricultural and Horticultural

Seedsmen and Nurserymen

\section{Mowbray, Cape Town}

Tel. Rondebosch 1. Telgms. 'Seedstarke, Mowbray.' $A N D$

\section{Charles Ayres}

The Cape Florist, Nurseryman and Seedsman

The Nurseries, Liesbeek Rd., Rosebank (Tel. Rondebosch 100)

Seed Store :

118 St. George's St., Cape Toظn Telephone 778 Central Telegrams : 'Ayres.' 


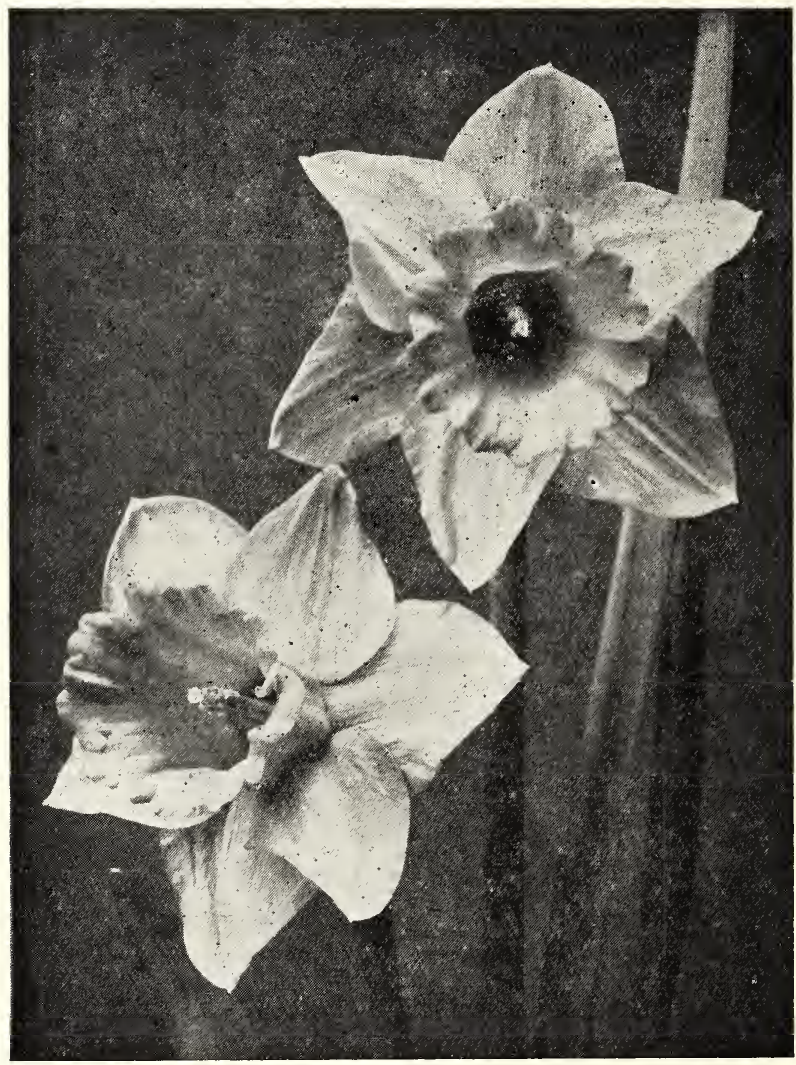

DAFFODILS, "KING ALFRED." 


\section{BULBS \\ AND \\ BULBOUS PLANTS \\ FOR \\ 1931}

It will always be our endeavour to supply the very best Bulbs, true to the description given in this catalogue, but it is a condition of sale of all Bulbs sent out by us, that, though we give you our assurance that we are using all reasonable care in the selection, we accept no responsibility In regard to the crop or failure of crop. All orders are booked on the understanding that these conditions are agreed to and we also notify to the same effect on the invoice. If the conditions are not acceptable to you the goods should be returned at once.

Quotations are without engagement, but where the price is mentioned on the order we will refer back for confirmation if an increased rate has to be charged. If we fail to do this, the goods can be returned if the price is not approved.

When we are unable to supply the exact variety ordered, we use our best judgment as to substituting other varieties. Any such substitutions are always made with a due regard to season, locality and other conditions so far as known to us.

The substituted varieties are sent for your approval, and while we hope and feel sure you will agree to what we have done with a desire to serve your best interests, you are at liberty to send back any such goods and we will promptly credit you with their value.

Send the money with your order for Bulbs and we will pack free and pay the postage provided the address is within the Union!

Bulb Orders are executed at

AYRES' NURSERIES, ROSEBANK, CAPE. 


\section{ANEMONES.}

\section{De Caen (Excelsior}

Price doz. 100
Mixture) Single
$1 / 6 \quad 10 / 6$

Giant blooms on long stems, magnificent colours in great variety.

Fulgens Multipetale Semi-double

$3 /-\quad 18 / 6$ Dazzling scarlet, very beautiful.

His Excellency ... Single

$2 /-12 / 6$

Scarlet, very large.
L'Unique
... Single
$3 /-\quad 22 / 6$

Beautiful salmon-pink.

Sylphide

... Single

$2 / 3 \quad 16 / 6$

Violet; large flowers on long stems.
St. Brigid
Semi-Double
$2 /-\quad 13 / 6$

These are a great improvement on the single varieties, mostly semi-double, and are very freeflowering, splendid mixture.

\section{ARUMS.}

Dracunculus

A remarkable

flower resembling a black Arum. The spathe is of a rich deep purple colour.

Zantedeschia

\section{Aethiopica Arum}

Price each do\%.

$$
\text { ... Dragon Plant } 1 / 6
$$$$
\text { plant produc }
$$

large

The Cape White Arum. Easily grown as it
arlapts itself to summer or winter rainfall.

\section{Zantedeschia}

Per $10022 / 6$
$2 / 6 \quad 25 /-$

Pure white with spotted foliage.

\section{Zantedeschia}

Angustiloba Arum

Yellow with dark blotch in spathe.

$2 / 6 \quad 25 /$. 


\section{ARUMS. Price each doz.}

\section{Elliottiana Arum}

A beautiful species, having dark green leaves with silvery spots and deep yellow spathe. making a very showy flower.

Zantedeschia Sancta Arum $3 / 6 \quad 366_{\text {, }}$. The black Arum.

\section{Zantedeschia}

Solfaterre Arum

Light yellow with black centre, strong growel.

\section{CANNAS.}

Single bulbs charged $3 d$ less when included in a dozen. Price each doz.
Africa
Bronze-leaved
$1 / 3 \quad 10 / 6$

Rich purple-scarlet, orange and gold inside, leaves purple-bronze striped green with dark green shades, flowers large.

\section{Bridesmaid}

Pale rose-pink, bronze foliage.

Bronze Giant ‥ Bronze-leaved 9 d $5 /$ -
Orange-scarlet, small flower, dense bronze foliage, splendid for back lines, a perfect setting for other varieties, tall, $8 \mathrm{ft}$.

Per $10030 /-$

\section{Connemara}

$$
\text { ... Green-leaved }
$$

Crimson with a narrow gold edge.
Dreamer
Green-leaved
$1 / 3 \quad 10 / 6$

Orange-scarlet, edged gold.

Fire Bird ... Green-leaved

Pure scarlet, perfectly formed Amaryllis-like bloom, considered the best Canna in existence, green foliage.

Bulb Orders are executed at AYRES' NURSERIES, ROSEBANK, CAPE. 


\section{CANNAS.}

Italia

Green-leaved

Enormous panicles of scarlet flowers with a

Price each doz. yellow border.

J. B. van der Schoot Green-leaved

Dark citron-yellow spotted purplish red, extra broad flowers, very large, very bioad green foliage.

$\begin{array}{llll}\text { King Humbert } \quad \ldots \quad \text { Bronze-leaved } & 1 / 3 & 10 / 6\end{array}$ Brilliant orange-scarlet with bright red markings, gigantic flowers, bronze foliage, excellent.

King of the Scarlets Green-leaved

Brilliant scarlet, green foliage, probably the best of this colour.

$\begin{array}{lllll}\text { Orange King } \quad \ldots & \text { Green-leaved } & 1 / 3 & 10 / 6\end{array}$ A dominating shade of orange, very fine.

$\begin{array}{lllll}\text { Parthenope } & \ldots & \text { Green-leaved } & 1 / 3 & 10 / 6\end{array}$ Vivid dark orange-yellow edged a darker shade, enormous spikes, foliage glaucous green.

Professor David A. Green-leaved $\quad 1 / 3 \quad 10 / 6$ Orange and gold.

Stadsrad Heinrich ... Bronze-leaved $\quad 1 / 3 \quad 10 / 6$ Orange-scarlet, bronze foliage, strong grower, $4 \mathrm{ft}$.

\section{BULB FIBRE.}

Specially prepared for growing Bulbs indoors. DAFFODILS and HYACINTHS can be easily grown in shallow bowls containing this FIBRE which must be kept just moist but not too wet during the growing period. They may be started as early as February and you will be surprised how soon they will flower. Bring them close to the light when leaf growth has well started.

BULB FIBRE.-Per lb 9d; $12 \mathrm{lbs}$ at $8 \mathrm{~d}$; per sack 25/-. 


\section{DAFFODILS AND OTHER NARCISSI.}

Price doz. 100
Admiration
... Poetaz Hybrid
$3 / 6 \quad 22 / 6$

Beautiful deep yellow with conspicuous red eye.

Aspasia

... Poetaz Hybrid

$3 / 6 \quad 22 / 6$

Broad solid white perianth and golden cup, prettily fluted, four to five large bold flower's orl a stem.

\section{Barri Conspicuus Barri}

Yellow petals and very fine scarlet cup.

\section{Cervantes \\ ... Bicolor Trumpet \\ $2 /-10 /-$}

Clear sulphur perianth and yellow cup, nicely frilled. Very free-flowering and produces the earliest blooms.

Per 1000 85/.

Elvira $\quad \ldots$ Poetaz Hybrid $3 / 6 \quad 2 \cdot 2 / 6$ Broad white petals and golden yellow cup, 4 to 6 flowers on a stem.

Emperor $\quad \ldots$ Yellow Trumpet
Very large flower with brilliant yellow trumpet.

$\begin{array}{llllll}\text { Empress } & \ldots & \text { Bicolor } & \text { Trumpet } & 3 / 6 & 22 / 6\end{array}$ Large flower with white perianth and rich yellow trumpet.

Grand Primo $\quad$... Polyanthus

A cluster-flowered Narciss, white with prim$3 / 6 \quad 22 / 6$ rose yellow cup. Per $100030 /$ -

Grand Soleil d'Or ... Polyanthus $\quad 2 / 6 \quad 17 / 6$ Cluster-flowered, yellow with orange cup.

Herbert Smith … Yellow Trumpet 20/-150/Deep yellow, very large trumpet, splendid form and great substance. $2 /$-each

Take advantage of our offer of Free Postage and Packing by sending Cash with your Order. 


\section{DAFFODILS.}

Jonquil

... Single

Price doz. 100

Pure yellow, sweet scented.

$2 / 6 \quad 15 /-$

King Alfred $\quad .$. Yellow Trumpet 20/- 150/The Giant Golden Trumpet Daffodil, great size and substance, irtense rich gold, a great prize winner.

Lucifer - Incomparabilis 2/- each.

Perianth white, cup intense glowing orange, trong grower, long stems.

Odorus Regulosus ... Campernel

The Campernel Jonquil, large-flowering type, $3 / 6 \quad 22 / 6$ golden yellow, early and tree-flowering.

Odorus Regulosus

Plenus Campernel

$3 / 6 \quad 22 / 6$

Double Campernel Jonquil.

Paper White ... Polyanthus

Pure white, cluster-flowered, splendid cutflower.

Seagull

... Barri

Per $100070 /$.

White perianth, expanded canary yellow cup, free-flowering and tall.

Sir Watkin $\quad .$. Incomparabilis

The largest and finest of this type, long stems and a magnificent bloom.

Snowdrops $\quad$... Leucojum

Pretty white bell-shaped flowers tipped green, six or more on a scape $1 \mathrm{ft}$. long. Per 1000 40/Victoria

Bicolor Trumpet

$3 /-\quad 20 /-$

$2 /-10 /-$

$3 / 6 \quad 22 / 6$

Fine yellow trumpet and white petals, freeflowering.

Finest Mixture of All Daffodils

We supply an excellent assortment from our fine rollection

Send Caslı with your Order and save Postage. 


\section{GLADIOLI.}

In this section we are listing a very fine range of all the most popular hybrid types as well as a choice range of individually named varieties of fine exhibition type. There is no more satisfying hobby than the cultivation of these intensely beautiful flowers and in South Africa they thrive as they do nowhere else for it is the home of numerous native species and the climate is quite suitable.

In over-seas catalogues most of the dwarf types are described as "early-flowering," but we think the term misleading for South Africa and from our experience we would suggest that most of the dwarf varieties will be found useful for spring planting to flower in summer after the larger types have finished blooming, thus providing a longer flowering period for these popular plants.

Single Bulbs charged $3 d$. less when included in a dozen.
Adelaide de
Price each doz.

Luxembourgh Garden Hybrid $9 \mathrm{~d} \quad 3 / 3$

Light rose with white blotch. Per 100 24/-.
Alice Tiplady
Primulinus Hybrid
$9 d$
$3 / 3$

Beautiful orange-saffron, splendid for cut-flower.

Per 100 24/-.

America ... Garden Hybrid ad 2/9

Bright lilac-rose, very large spikes.

Argo $\quad \ldots$ Frimulinus Hybrid $1 / 3 \quad 9 /$ -

Delicate pink, tall spike, large flowers.

Blushing Bride ... Garden Hybrid $9 \mathrm{~d} \quad 3 /-$ Same as "Willy Wigman." Creamy white with soft carmine blotch.

Brenchleyensis ... Garden Hybrid $9 d \quad 2 / 6$ Vermilion scarlet. Per $10018,6$.

Buttercup ... Primulinus Hybrid $1 /-\quad 6 / 3$ Bright golden yellow.

Captain Fryatt ... Garden Hybrid $9 \mathrm{~d}$ 3/A very fine dark red. Per 100 22/6.

Chris

... Garden Hybrid

$9 d \quad 2 / 6$

Dark maroon, shaded purple. Per $10018 / 6$. 
Clear Eye

Brilliant scarlet with pure white blotch, large wide open flowers well placed on the stem.

Clemenceau Per $10022 / 6$. Blood red, a very strong grower.

Colvilli Rubra

\section{Improved Dwarf}

$8 d$

Rosy purple with darker shading and white stripes.

\section{Crimson Glow} Per $10010 / 6$.

A perfect scarlet of a deep tone, large open flowers of finest form. Per 100 26/-.

Dawn

... Garden Hybrid

$9 d \quad 3 /-$

A long and graceful spike of salmon-pink flowers all open at practically the same time.

\section{Delicatissima}

Per 100 18/6.

\section{Superbissima Dwarf}

Like "Blushing Bride" but finer bloom.

$$
\text { Per } 10030 / \text {. }
$$

Duchess of York ... Garden H!jbrid 10d $3 / 6$ Fine blue, very free flowering and good for decoration.

Per 100 26/.

Eurydice

Primulinus Hybrid

$6 d \quad 4 / 6$

Satin rose with delicate markings on the lower segments.

Per 100 22/6.

F.aust

Dark velvet-red, large flower. Per 100 22/6.

Feu Ardent $\quad$... Primulinus Hyhrid 1/- 6/3

Beautiful carmine-red, good substance, very striking.

Fire Queen

Primulinus Hybrid 1/-

$6 / 3$

A splendid bright scarlet primulinus, very fine.

Flaming Sword

Garden Hybrid

$9 d \quad 3 /-$

A bright red, free-flowering variety of strong growing habit. 


\section{GLADIOLI.}

$\begin{array}{llllll}\text { Frau Dr. Hauff } \quad \ldots \text { Garden Hybrid } & 1 / 2 & 7 / 6\end{array}$ Glistening scallet; very attractive.

Generaal De Wet ... Garden Hybrid $1 /-\quad 6 / 3$ Apricot-rose, fiower's well shaped and open, the petals being somewhat recurved, a giand variety.

General Petain $\ldots$ Garden Hybrid
Bright scarlet with white blotch. Per 100 20/-. Gigantic $\quad \ldots$ Garden Hybrid 4/ 376 Bright rosy red shaded salmon. Probably the largest of all Gladioli.

Glory of Holland ... Gurden Hybrid 10d $3 / 9$ P'ure white. Per $10027 / 6$.

Golden Measure ... Garden Hybrid $1 / 8$ 14/. Beautiful yellow with well opened flowers; one of the best of this colour.

Halley

Garden Hybrid

Bright orange-rose with a yellowish tint in the throat; produces immense spikes of large blooms.

Per $10015 \%$.

Herada

Giarden Hybrid

$9 \mathrm{~d}$

$2 / 9$

Pure clear glistening mauve, immense blooms on tall straight stems, very striking.

Herr Kanzleiter ... Garden Hybrid 3/- 30/lirilliant dark blood red.

Juno

Primutinus Hybrid

9d $2: 3$ Delicate salmon with yellow falls. Per $10017 /$.

Liebesfewer

... Garden Hybrid

$10 d \quad 4 / 6$

(Lovefire.) Brilliant red, very large flower.

L'Immaculee $\ldots$ Garden Hybrid
Pure white flower's, splendid for cutting.
Per $10033 / 6$.

10d 4 e 
GLADIOLI. Price each doz.

Madame Petain ... Primulinus Hybrid 1/- 5/Soft rosy lilac, flushed silvery white, very graceful.

Maiden's Blush ... Primulinus Hybrid $8 \mathrm{~d} \quad 2 /$ (Enchantress). Beautiful delicate pink, stems tall and slender, splendid cut-flower.

Per 100 15/-.

Marechal Foch ... Garden Hybrid 8d 2/Beautiful clear pink, strong grower. Per 100 15/-.

Mary Pickford . .. Garden Hybrid 10d $4 / 6$ Delicate creamy white, throat finest soft sulphur-yellow. Per 100 33/6.

Meilust $\quad \ldots$ Garden Hybrid $9 \mathrm{~d} \quad 2 / 6$ Lovely pink with dark pink blotch on the lower petal. Per 100 18/6.

Mirs. C. P. Alkemade Garden Hybrid 9d $3 / 3$ Pure white; strong grower; about a week earlier than "White Giant." Per 100 24/-.

N.rs. Frank

Pendleton, Jr. Garden Hybrid

Soft rose with purple spot. Per 100 18/6.

Mrs. Grullemans ... Primulinus Hybrid 2/- 20/Pure golden yellow, quite distinct from the ordinary yellow Primulinus.

Mrs. Potter Palmer... (iurden IIytrid

lieepp purple-violet, a most beauliful Hower

Orange Brilliant ... Primulinus Hybrid od 2/9 A most attractive variety, the name amply describes its colour. Per 100 20\%

$\begin{array}{lllll}\text { Orange King } \quad \ldots & \text { Farden Hyorid } & 1 / 6 & 11 / 3\end{array}$ Pure orange, large and free flowering, very early. Orange Queen … Frimulinus Hybrid $1 / 6 \quad 12 / 6$ Beautiful orange; large flowers on strong stems. Per $10017 / \cdot$. 


\section{GLADIOLI.}

Price each doz.

Pink Perfection ... Garden Hybrid 9d $2 / 9$ Delicate apple-blossom with a white stripe and dark rose feathered border. Per 100 20/-.

Pride of Haarlem ... Garien Hybrid $1 / 3 \quad 9 /-$ Rich salmon-cherry-red shaded with fawn, a grand new variety.

Prince of Wales ... Garden Hybrid Beautiful salmon-red shaded silvery white.

Per 100 15/.

Princeps

Garden Hybrid

$9 \mathrm{~d} \quad 2 / 3$

Large flowers of a bright scarlet colour.

Per $10017 /$.

Red Canna $\quad$ Garden Hybrid
Large bright red flowers.

Red Emperor $\quad .$.
Red, extra large flower.

Rcine Victoria

Primulinus Hybrid

$812 \quad 2-$

Deep pink shaded silvery rose, flowers larger than usual for this type but of a most heant. ful form.

Per $10027 / 6$.

Rose Luisants ... Primuirinus Hybrid

$10 \mathrm{~d} \quad 3 \%$

Brilliant deep rose-pink shaded white, a flower of great heruty and refinement. Per $10027 / 6$.

Rose Precose ... Gurden Hybrid

$9 \mathrm{~d} \quad 29$

Salmon pink, feathered dark pink; large flower and strong grower. Per $10020 /$ -

Rubini

Garden Hybrid

$9 d \quad 26$

$9 d \quad 3 /=$

10d 39

Orange-scarlet, with white blotch. Per 100 20/-. Ruffled Gem Girden Hybrid

9 d $2 / 9$

Delicate pink; large flower on strong stem.

Per $10022 / 6$.

Salmonea

Primulinus Hybrid

$9 \mathrm{~d} \quad 2 / 3$

Bright scarlet, very fine for decorative purposes.

$9 d \quad 3 /-$

Per 100 17/-. 


\section{GLADIOLI. Price each doz.}

\section{Scarletta \\ Primulinus Hybrid 9d \\ $2 / 6$}

Beautiful scarlet flowers on tall delicate stems.

Per 100 18/6.

Sonia

Primulinus Hybrid

$1 / 2 \quad 7 / 6$

Large bright red, an unusual colour among the Primulinus varieties.

Sunrise

Primulinus Hybrid $1 / 2 \quad 7 / 6$

Light yellow shaded orange, fringed flowers, very attractive.

Sweetheart

Garden Hybrid

$1 / 6 \quad 12 / 6$

Delicate cherry-rose, shaded silvery rose; usually six to eight pips open together; a very beautiful variety.

Viclet of Parma

Garden Hybrid

$1 / 3 \quad 8 / 9$

Pure violet with white centre and feathered white; the cnly variety in this colour.

War Garden Ilybrid

$9 d \quad 3 i^{\prime}-$

Deep blood red, shaded crimson-black.

Per $10022 / 6$.

White Butterfly ... F'rimulinus Hybrid 10d 4/3

$\Lambda$ pure white Primulinus; fine slender stem;

a delicate cut-flower. Per 100 32/.

White City $\quad \ldots$ Garden Hyhrid

Per 100 30/.

White Giant

Garden Hybrid

$10 \mathrm{~d} 4 /-$

A white variety of great excellence.

White Glory

Garden Hybrid

$1 /-5 /-$

A bemtiful white with an Iris-blue throat, verv fire.

Willbrink

... Garden Hybrid

$9 d$

$2 / 3$

Flesh-pink with creamy blotch in centre, early.

Per 100 17/-.

Send the money with your Order for Bulbs and we will pack free and pay the postage provided the address is within the Union! 


\section{GLADIOLI.}

Price each doz.

Yellow Hammer ... Gorden Hybrid 9d $2 / 6$ A good bedding variety. Per 100 18/6.

Yellow Standard ... Gurden Hybrid $9 \mathrm{~d} \quad 2 / 6$ Large yellow flowers and a strong grower.

Per 100 18/6.

Primulinus Hybrids ( $\mathrm{Fer} 10010 / 6$ )

$A$ new race of hybrids produced by crossing the beautiful primrose-yellow "Gladiolus primnlinus" with some of the hest garden varieties.

Rosehank Mixcure ...

An assortment of superior varieties from our yrawl collertion. l'er 100 15/-.

Mixed Hybrids ...(Per $10010 / 6) \quad-\quad 16$

\section{NATIVE SPECIES.}
Gladiolus Alatus ... "Kallioentjie",
Gladiolus Aletroides "Flumes"
1 i- $5 /-$

Price each doz.

Gladiolus Blandis ... I'er $10037 /$.

l'er' $10022 / 6$.

Gladiolus Blandis

var. Carminea

$1: 76$

Gladiclus Hirsutus ...

$1 / 310 /-$

Rosy mauve: varies; scented.

"Painted Lady" ...

$8 \mathrm{~d} 2 /-$

White with pink markings in the lower petal,

a very beautiful South $\lambda$ frican variety.

Per $10015 /$.

Bulb Orders are executed at

AYRES' NURSERIES, ROSEBANK, CAPE. 


\section{HYACINTHS.}

Single Bulbs charged 3d. less when included in a dozen.

City of Haarlem ... s'inyle

Price each doz.

Bright golden vellow.

General Vetter ... Single

Blush white, large truss.

Gigantea

... Single

$2 /-\quad 17 / 6$

Pale rose, large spike.

Grand Maitre ... Single

Deep porcelain blue, very firte.

$2 / 6 \quad 25 /$.

$2 /-17 / 6$

$1 / 915 /-$

\section{Honneur}

Wine red.

\section{D'Leidschedam Single}

$2 /-17 / 6$

King of the Blues ... Single

$2 /-\quad 17 / 6$

Bright dark blue.

King of the Yellows Single

$2 /-17 / 6$

Fine deep yellow.

Lady Derby ... Single

Soft blush shaded pink, splendid spike with large bells.

La Grandesse ... Single

Pure white, long full spike of splemlid form.

\section{La Victorie ... Single}

$2 /-\quad 17 / 6$

Bright glistening red, a beautiful and brilliant variety.

L'Esperance ... Single

$2 i-17 / 6$

$2 /-17 / 6$ Purple.

L'Innocence ... Single

Pure white, a fine truss with large bells.

Per 100 100/-

\section{Lord Balfour ... Sinyle}

Lilac-rose tinged dark violet. very early.

Marie

... Single

$2 /-\quad 17 / 6$

Dark blue.

$1 / 9 \quad 15 /-$

$1 / 915 /-$

$2 /-\quad 17 / 6$ 


\section{HYACINTHS.}

Moreno

Single

Bright pink with darker stripe, large bells and spike.
Orange Glow
... Single
$1 / 915 /-$
Orangey yellow.
Perle Brilliant ... Single
$2 /-17 / 6$

Outside blue, inside pale blue, sturdy stems,

Price each doz. very fine.

Queen of the Blues... Single

Beautiful light porcelain blue, large compact

$1 / 9 \quad 15 /-$ spike with bells of medium size.

Queen of the Pinks... Single Lovely pink, large truss and strong stem, very fine.

Regulus Clear blue.
... Single

Per 100 100/-.

\section{Roi Des Belges ... Single}

Clear rosy crimson.

Roman

... White

Early Italian: dainty white flowers on slender stenis; splendid cut flower.

Roman

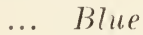

Dainty blooms; a delightful colour.

Roman

... Pink

$2-17 / C$

Charming cut flower.

Yellow Hammer ... Single

One of the best of this colour.

Double Blue and Dark Blue

Single Blue and Dark Blue

Single White

Single Mixed

$1 / 9 \quad 15 /-$

$1 / 9 \quad 15 / \cdot$

$1 / 9 \quad 15 /-$

$1 / 310 /-$

Why not send the money with your Order and thus save the Postage? 


\section{IRISES. \\ Bulbous Section.}

Price do\% 100

\section{Anton Mauve \\ Dutch}

$2 /-12 / 6$

Soft blue, very fine.

Count of Nassau ... Spanish

The best dark blue, sweetiy sceuted

Flora

Spanish.

$2 /-12 / 6$

$2 /-12 / 6$

Light blue and white, very large.

King of the Blues Spanish

Sweet scented.

Leânder

... Spanish

$2 / 26$

Dark yellow.

Prince Henry

Large purplish bronze, one of the hest of the bronze varieties.

Queen Wilhelmina Snanish.

Pure white, strong grower.

Surbiton

... Spmanish

Verv dark yeliow.

Tingitana

Pale lilac-blue, bulbous.

\section{Rhizomatous Section. \\ Regelio-Cyclus Group.}

Single Bulbs are charged $3 \mathrm{~d}$. less when included in a dozen.

Price dur.

\section{Artemis}

... Regelio-Cyclus

Violet-purple, veined dark purple with black spots, tall, large flower.

\section{Beatrix}

... Regelio-Cyclus

Soft pearl grey with dark violet veining. Charon Regelio-Cyclus

$2 /-\quad 12 / 6$

$2 /-\quad 12 / 6$

$6 / 6 \quad 40 /-$

Dark brown, veined black.

\section{Bulb Orders are executed at}

\section{AYRES' NURSERIES, ROSEBANK, CAPE.}




\section{IRISES.}

Hecate

Upper petals soft rosy white, lower petals veined brown and bronze on a silvery ground.

Isis

$$
\text { ... Regelio-Cyclus }
$$

Ruby red with grey and purple reins, very large.

Parthenope

$$
\text { ... Regelio-Cyclus }
$$

Lilac and white, veined purple.

Una

Nark brown with violet veining

Price each doz.

$3 / 6$

... Regelio-Cyclus

$3 / \cdot$

\section{Miscellaneous.}

Single Bulbs charged $3 \mathrm{~d}$. less when included in a dozen.

Price each doz
Alcazer
Squalens
$2 /-18 \%$.

Light blue and bronze.

Celeste

$$
\text { ... Pallida }
$$

Sky blue.

Dalmatica

(Princess Beatrice).

Florentina

$$
\text { Pallicla }
$$

$2 / 6$

9d 3/.

Large white, sweet scented, tall gruwer

Per $10020 /$.

Purple King

... Germanica

$1 /-$

$6 /-$

(Atroviolaceal). Purple-violet.

Stylosa, Mauve ... Beardless

A beautiful Algerian Iris of dwarf habit, grass-like foliage, lovely mauve flowers on slender stems up to 12 inches, autumn-flnwering.

Per 10076

Send the money with your Order for Bulbs and we will pack free and pay the postage provided the address is within the Union: 
Blue

Incarnata

Leucantha (Mauve)

Leucantha (White)

Lutea

Yellow.

Maculata

Yellow with black centre.

Scariosa

Mauvy flowers with yellow throat, very dainty. Viridiflora

Light green with purple eye.

Finest Mixed
Price doz. 100

$1 / 6 \quad 10 / 6$

$4 / 6 \quad 30 /-$

$1 / 6 \quad 10 / 6$

$1 / 6 \quad 10 / 6$

$1 / 6 \quad 10 / 6$

$1 / 3 \quad 7 / 6$

$1 / 6 \quad 10 / 6$ $4 / 6 \quad 30 /-$

$1 / 3 \quad 7 / 6$

\section{LILIUMS.}

Single Bulbs charged 3d. less when included in a dozen.

Price eacb doz.
Candidum
... Madonna Lily
$2 /-20 /-$

A truly elegant bloom, pure white.

\section{Longiflorum}

Formosum White Japanese

Pure white, sweetly scented.

$$
\text { Lily } 2 / 6 \quad 25 i^{-}
$$

Regale

A vigorous grower with sturdy stems, 4 to 5

$1 / 6 \quad 12 /-$

ft., covered with long lanceolate foliage; centre of flower flushed with yellow, shading to white at the outer edges; outside streaked with brown; exceedingly beautiful; thrives in any good rich soil and is the easiest of all lilies to grow.

Take advantage of cur offer of Free Postage and Packing by sending Cash with your Order. 


\section{LILIUMS.}

Speciosum Album ...

One of the most beautiful Japanese Lilies in

Price each doz.

$2 / 625 /-$ cultivation, large open flower's with recurved petals, 2 to $3 \mathrm{ft}$. stems.

Speciosum Rubrum

This differs only in colour from the "Album"

$2 / 6 \quad 25 /-$ variety, having red or purplish suffusions and blotches.

Thunbergianum

Tigrinum

Alutaceum $1 / 9 \quad 15 /=$

Flore Pleno

The double Tiger Lily, scarlet-orange.

Tigrinum Sinense ... $1 / 3 \quad 8 / 6$

Deep orange-red flowers heavily blotched purple, $1 / 3 \quad 10 / 6$ stems 2 to $4 \mathrm{ft}$.

RANUNCULUS.

Emperor of China... French

Price doz. 100 Pure yellow.

Fire Ball ... Persian

Vermilion, large flower.

Orange Brilliant ... Persian

Deep yellow, tinged orange, black centre.

Vermilion Brilliant ... F'rench

Vermilion-red.

Viridiflora

... Turban

$1 / 6 \quad 8 / 6$

Scarlet with greenish centre.

French, Finest mixed

Turban, Finest mixed

$1 / 6 \quad 8 / 6$

$2 /-12 / 6$

$1 / 6 \quad 7 / 6$

$2 /-12 / 6$

$1 /-\quad 6 /-$

$2 /-12 / 6$

Send the money with ycur Order for Bulbs and we will pack free and pay the postage r.rovided the address is within the Union! 


\section{WATSONIAS.}

Single Bulbs charged $3 \mathrm{~d}$. less when included in a dozen. Price each doz.

Adelaide

Orange-scarlet.

Brighton Purple.

Brisbane
... Cronin Hybrid Per $10010 / 6$.

Bright crimson-scarlet.

\section{Caulfield}

Delicate pink.

Lol'ne Rose-pink with deeper throat.

Melbourne Shell pink, deeper throat.
Cronin Hybrid

Cronin Hybrid

Per 100 8/6
$1 /-\quad 7 / 6$

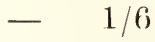

$-1 / 9$

Muizenberg

Orange-scarlet, tall grower, late flowering (January).

Per $10010 / 6$.

Orange Beauty ... Selection
Beautiful deep orange, fine colour, long-stemmed.

\section{Pretoria}

... Hybrid

$1 /-\quad 7 / 6$

Mauvy pink shading to magenta. Per $1008 / 6 ; 100075 /$.

Sydney ... Cronin Hybrid
Per 100 10/6. ... Cronin Hybrid
Per 100 10/6.

Mauve, deeper edge.

Victoria Cronin Hybrid

$1 /-\quad 7 / 6$ Deep red, long tube. Watsonia Angusta ... "Scarlet" Gives a very fine spike of scarlet flowers. Per $1008 / 6$.

\section{Watsonia Beatricis}

Long spikes with numerous orange-red flowers opening mostly at one time; evergreen foliage; nuust be watered in the dry season. 


\section{WATSONIAS.}

Watsonia Galpini

Yrice each doz.

Dark red, very fine spikes.

$$
1 /-\quad 7 / 6
$$

Watsonia Iridifolia ...

A very pretty species with characteristic Howers, greenish ivory colour on opening changing to cream.

Per $1008 / 6$

Watsonia Longifolia Salmon-orange

Evergreen foliage; must be watered in the dry season.

$$
\text { Per } 1008 / 6 \text {. }
$$

Watsonia Marginata

$A$ fine species with beautiful delicate pink flowers o:1 a very tall stem. Pe: 100 20/.

Watsonia Meriana ... "Suurknol"

Narrow-tubed flowers of a delicate crushed strawberry shade. Colour is somewhat variable in this species. Per $1008 / 6$.

\section{Watsonia Rosea}

The Pink Watsonia of Table Mountain; very showy.

Watsonia Rosea Per $1008 / 6$; $100075 /$. .

\section{var. Alba}

Arderne's Watsonia.

This is a beautiful White Watsonia introduced into cultivation by the late Mr. H. M. Arderne. $1008 / 6 ; 100075 /$ -

Watsonia Hybrids ... Mixed

Per $1008 / 6 ; 100075 /-$.

Just

Right

for

Bulbs.

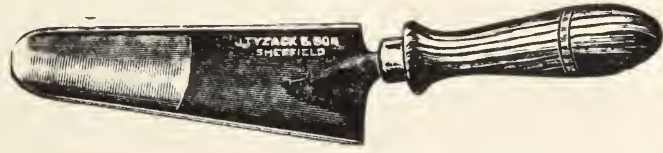

FFn88-6 in. 1/2 each. Postage 4il. 


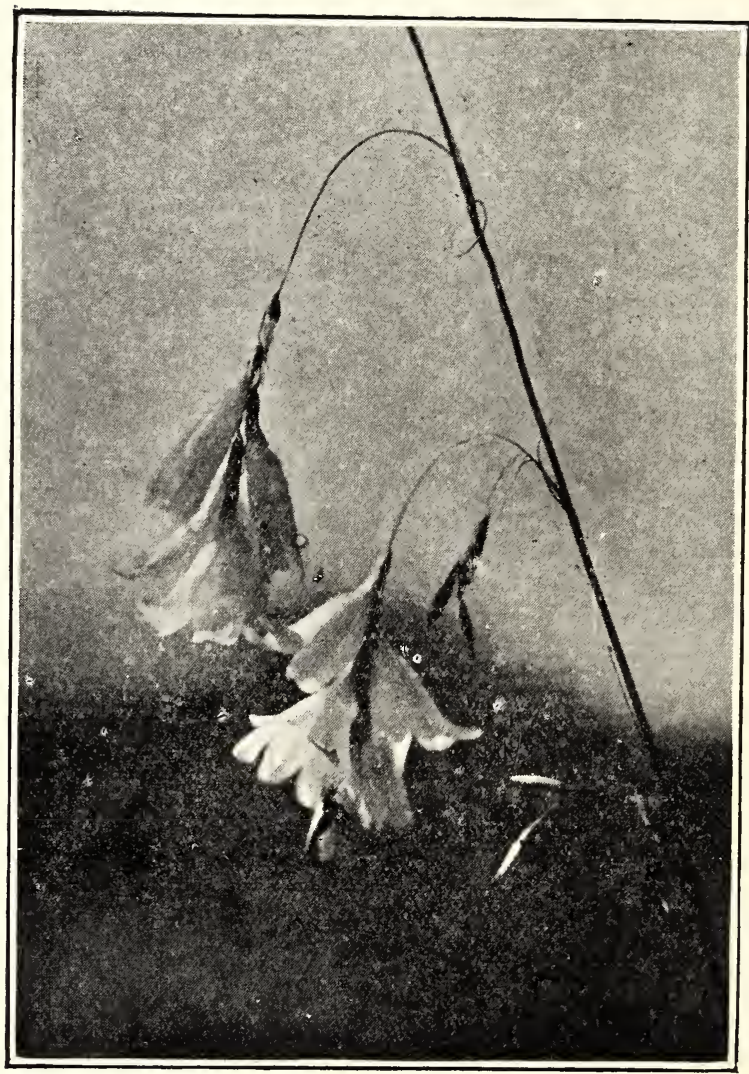

DIERAMA PENDULUM.

24 


\section{MISCELLANEOUS.}

Agapanthus

Magnificent umbels of blue flowers, veined lighter blue, borne on a tall scape. A very striking plant Also a white variety.
Agapanthus
Duarf
$1 / 3 \quad 8 / 6$

The Table Mountain variety; intense dark blue; very beautiful.

Alstromeria Hybrids

Alstromeria sp. ... Yellow

Amaryllis Belladonna March Tily

Bears six to twelve sweetly scented fummel-

$9 \mathrm{~d} \quad 4 / 6$

$1 ;-6 /=$

shaped flowers on a tall stem, colour varies from almost white to deep pink.

Antholyza Merianella

Antholyza Praealta... Cape Antholyza

Per 100 15/-.

Showy orange-red blooms, well above the foliage. Thrives in shady positions, but the best blooms are produced in the open.

Per 100 6/.. $100050 /$.

\section{Aponogeton}

Distachyon Cape Pondweed 1/- 6/6 Sweet-scented white flowers during winter; leaves float on the surface of the water.

Aristaea Capitata ...

A magnificent bulkous plant with deep blue flowers on a spike four or five feet high.

$1 / 6$

Per 100 15/-.

Babiana, Purple Self

A striking variety.

Per $1008 / 6$.

Babiana Stricta

Light blue.

Per $1008 / 6$.

Babiana Stricta ... "Sulplıurea"

$2 / 6$

Milk-white, fine blooms. Per 100 10/6. 


\section{MISCELLANEOUS.}

Babiana, Mixed

Price each doz. Splendid mixture. Per 100 8/6, $100075 /$ -

\section{Clivia Hybrids}

Beautiful funnel-shaped flowers borne in umbels on a stout stem, very striking colours in deep yellow and orange. Larger specimens $5 /-$ and $7 / 6$.

\section{Crinum Longifolium}

Gives 6 to 8 large white flowers, usually flushed with red, on a strong stem.

Cyclamen

Hybrids

Dry corms, 1/- each, 10/- per dozen.

\section{Cyrtanthus obliquus}

Ten to twelve bright red drooping tubular

$2 /-20 /-$ flowers on a fairly stout stem.

\section{Dahlias}

Special list issued in season.

\section{Dierama Pendulum}

Soft rosy-white funnel-shaped flowers drooping gracefully from threadlike stalks carried on a tall flower stem, a charming plant.

Freesia Refracta

The sweetly scented blooms are produced in great profusion. Per $1004 / 6 ; 100037 / 6$.

Gloxinia ... Hybrids

A beautiful plant for pot culture.

Dry corms $1 /$ - each; 8/6 dozen.

\section{Haemanthus}

\section{Coccineus Maartbloem}

Umbels of bright red flowers produced in early autumn before the leaves appear.

Kniphofia Alooides ... Red Hot Poker

Gives a striking Aloe-like spike of red and yellow tubular flowers on long stems, more robust than "Kniphofia Rufa." Per 100 50/-. 


\section{MISCELLANEOUS.}

l'rice each, doz.

Lachenalia Orchioides

Lachenalia Pustulata

Per $10022 / 6$.

Lachenalia Tricolcr...

Leucojum

Pretty white bell-shaped flowers tipped green, six or more on a scape about $1 \mathrm{ft}$. long.

Per $1004 / 6 ; 1,00040 /$.

Moraea Iridioides ...

Iris-like flowers opening successively on a tall stem, thus remaining in bloom for a long time.

Nerine Alba

$A$ beautiful and free-flowering Nerine.

Nerine Sarniensis ... "Red"

$2 i$

Bright red, sparkling bloom.

Nerine Sarniensis ... "Sulmon",

$1 / 310 /-$

Nerine "Pink"

$1 / 3 \quad 10 /-$

A pretty variety of this beautiful flowering bulb.

\section{Ornithogalum}

\section{Arabicum}

The shining black ovary surrounded by the yellow anthers and creamy white petals make this a conspicuons flower. Per $1007 / 6$

\section{Ornithogalum,}

\section{Double White $1399 /-$}

A double form of the beautiful "Chinkerichee."

Ornithogalum Lacteum

"Darling" Chinkerichee. Flowers a few weeks later than the "Cape" variety.

Per 100 10/- ; 1000 90/- 


\section{MISCELLANEOUS.}

Ornithogalum

Price each doz.

\section{Thyrsoides}

"Cape" Chinkerichee. flowering variety.

Pancratium

White.

\section{The stamens are attached to}

This is the early Per $1007 / 6 ; 100060 \%$.

\section{Spider Lily}

cate cup-shaped membrane, while the long narrow petals dangle below.

\section{Satyrium Carneum ...}

The pink "Ewa trewa."

\section{Satyrium Coriifolium}

Commonly known as "Ewa trewa," fine spikes of bright orange flowers.

Scilla Campanulata... Beautiful bell-shaped

Spanish Bluebill scapes about 12 inches high. Per $1004 / 6$ Scilla Peruviana ...

Large pyramidal blue flower, in growth somewhat resembling the "Chinkerichee."

\section{Sparaxis Grandiflora "Cream"}

A delightful shade and gives a very nice

spray, useful cut-flower. "W Per $1008 / 6$ Sparaxis Grandiflora "White"

Resembles the Freesias but taller.

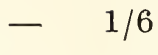

$1 / 3 \quad 7 / 6$ Per 100 50\%.

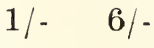

$1 /-6 /-$

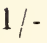

$1 / 3 \quad 7 / 6$

Per 100 5/-; 1000 40/-.

\section{Sparaxis Tricolor}

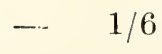

Beautiful Freesia-like flowers in various colours.

Sprekelia

Per 100 5/-; 1000 40/-.

\section{Formosissima}

A brilliant scarlet Amaryllid of exquisite form, easily grown in pots or open ground. Streptanthera Cuprea "Tangerine"

$2 / 6 \quad 22 / 6$

A beautiful Freesia-like flower of splendid form and lovely soft shade of tangerine. Per 100 8/6. 


\section{MISCELLANEOUS.}

Tritonia Crocata ... "Golden"

Price each doz.

Orange colour; Freesia-like flowers of great beauty.

Per 100 15/-.

Tritonia Hyalina ... "Salmon-pink", -. 2/6

We consider this the most beautiful of the Tritonias. Per $10015 /$ -

Tritonia $\quad \ldots$ Mixed
A very fine selection.
Per $10012 / 6$

Tuberose

Tulips

$\Lambda$ few acclimatised bulbs, various colours, Darwin type.

Vallota Purpurea ... Knysna Lily

Bright scarlet funnel-shaped flowers on a tall scape, a charming plant.

Zephyranthes Candida Suamp Lily

The pretty white flowers among the narrow dark green leaves make a fine show in mid. summer. Per $1003 / 6$; 1000 25/-

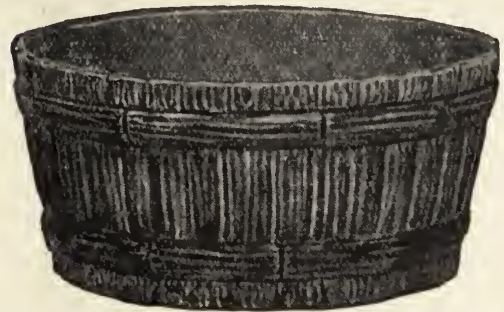

\section{BULB BOWLS.}

"Bamboo.",

Bronze Green

and Heliotrope

(Self Colours)

Prige each

7in. 3/-, 9in. 5/$\mathrm{F}$

Send the money with your order for Bulbs and we will pack free and pay the postage provided the address is within the Union! 


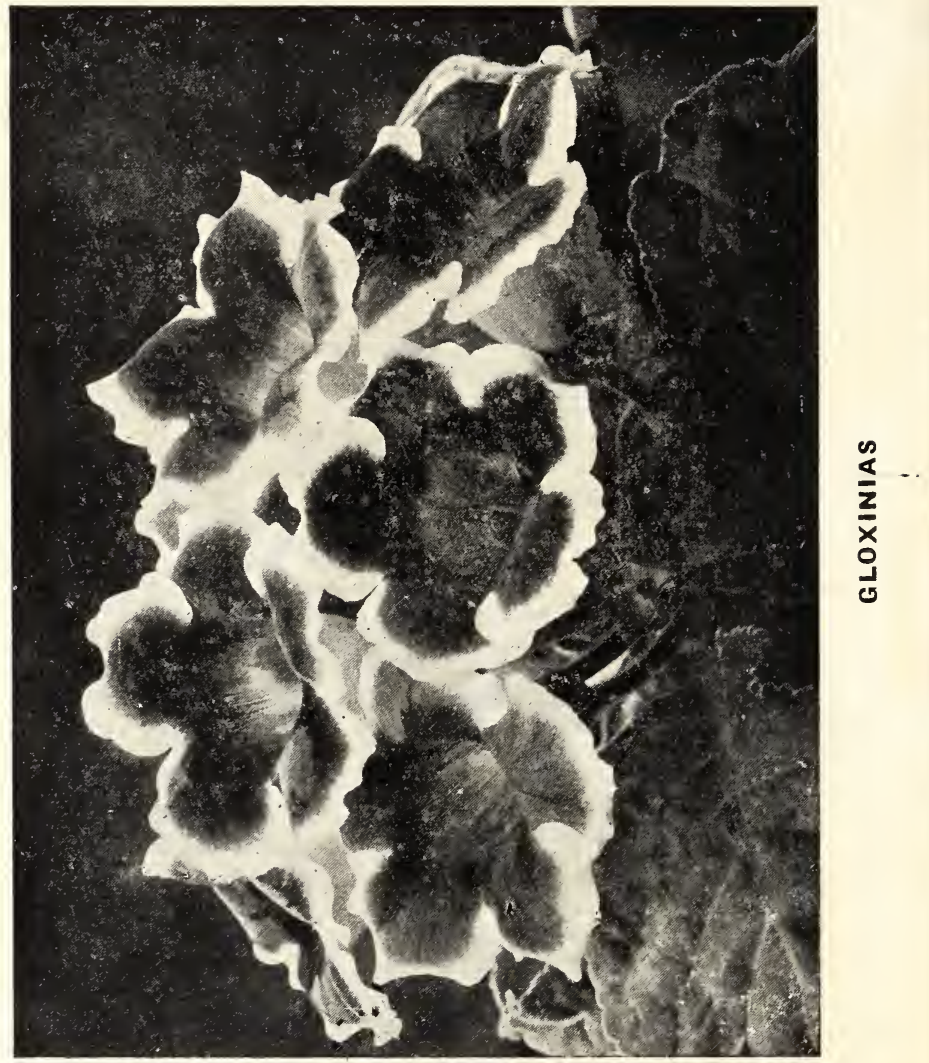

